\title{
The Prevalence and Distribution of Human Onchocerciasis in Two Senatorial Districts in Ebonyi State, Nigeria
}

\author{
Nworie Okoro ${ }^{1}$, Ukpabi Nkechinyere Nwali ${ }^{2}$, Oli Angus Nnamdi ${ }^{3, *}$, Okonkwo Chuma Innocent ${ }^{4}$, Okoli \\ Chukwudum Somadina ${ }^{2}$, Ejiofor Obiora Shedrack ${ }^{5}$
}

\begin{abstract}
${ }^{1}$ Department of Biological Sciences, Faculty of Science and Technology, Federal University Ndufu-alike, Ikwo, Ebonyi State ${ }^{2}$ Department of Applied Microbiology, Faculty of Biological Sciences, Ebonyi State University, Abakaliki, Ebonyi State, Nigeria ${ }^{3}$ Department of Pharmaceutical Microbiology and Biotechnology, Faculty of Pharmaceutical Sciences, Nnamdi Azikiwe University, Agulu Campus, Anambra State, Nigeria

${ }^{4}$ Department of Ophthalmology, Federal Teaching Hospital, Abakaliki, Ebonyi State, Nigeria

${ }^{5}$ Department of Pediatrics, Anambra State University Teaching Hospital, Amaku, Awka, Anambra State, Nigeria

*Corresponding author: oli_an@yahoo.com
\end{abstract}

Received February 02, 2014; Revised March 08, 2014; Accepted April 27, 2014

\begin{abstract}
Background: There has been a recent increase in the number of human Onchocerciasis cases in hospitals in Ebonyi Central. This study therefore sets out to determine the prevalence of the disease in Ebonyi North and Central Senatorial Zones of Ebonyi State as well as determine the age groups and sex most affected. Methods: This study was carried out in Ebonyi North and Central Senatorial Zones of Ebonyi State between January 2011 and April 2012, among subjects of 20-59 years. Diagnosis was by skin examination for onchocercal lesions, ocular examination for ocular lesion and parasitological examination for the presence of microfilariae of Onchocerca volvulus in skin biopsies and adult filariae in excised nodules. Results: Out of the 250 persons randomly examined in each zone, 82 (32.8\%) persons in Ebonyi Central zone comprising of 60 (38.7\%) males and 22 (23.1\%) females were found positive for Onchocerca volvulus while 73 (29.2\%) persons in Ebonyi North Zone comprising 48 (32.0\%) males and 25 (25.0\%) females. Chi-square test shows that male subjects had significantly higher diseases prevalence $(\mathrm{p}<0.05)$ than their female counterparts in the two zones but combined prevalence among male and female do not differ significantly in the two zones. The age group most affected was 50-59 years with the prevalence of $40.0 \%$ in Ebonyi Central and 38.6\% in Ebonyi North Zones. Out of the 155 (30.8\%) persons infected in the two zones, 28 (5.6\%) males and 14 (2.8\%) females had Onchocercal skin lesions, 57 (11.4\%) males and 22 (4.4\%) females had low vision. Partial blindness was observed in 16 (3.2\%) males and 8 (1.6\%) females. However, 7 (1.4\%) males and 3 (0.6\%) females had complete blindness. Farmers were mostly affected than any other occupational group. Conclusion: The findings obtained from this work suggested that Ebonyi Central and North Senatorial Zones are Onchocerciasis hypo-endemic Zones having the prevalence rate of $32.8 \%$ and $29.2 \%$ respectively. Sex, age and occupation are related to Onchocerciasis infections in both Zones. Males are more infected than females. Massive distribution of insecticides to destroy the vector Simulium damnosum (black fly), provision of adequate antiflarial drugs - ivermectin and mass health education targeted on preventive measures are highly recommended.
\end{abstract}

Keywords: onchocerciasis, ebonyi state, prevalence, neglected tropical disease

Cite This Article: Nworie Okoro, Ukpabi Nkechinyere Nwali, Oli Angus Nnamdi, Okonkwo Chuma Innocent, Okoli Chukwudum Somadina, and Ejiofor Obiora Shedrack, "The Prevalence and Distribution of Human Onchocerciasis in Two Senatorial Districts in Ebonyi State, Nigeria.” American Journal of Infectious Diseases and Microbiology, vol. 2, no. 2 (2014): 39-44. doi: 10.12691/ajidm-2-2-3.

\section{Introduction}

Onchocerciasis is an insidious non fatal filarial disease that has caused blindness, lifelong human suffering and grave socio-economic problems [1]. Also known as river blindness or Robles disease, it is a vector borne parasitic disease caused by the filarial worm - Onchocerca volvulus [2]. It is one of the tropical diseases classified as orphan or neglected disease and is the world's second leading infectious diseases [3,4]. The disease is a clinical syndrome partly or entirely characterized by dermatologic, ophthalmologic, lymphatic and sometimes systemic manifestations. The most serious lesions are those of the eye, which may lead to partial or total loss of vision [5]. The vast majority of infection occurs in sub-Saharan Africa, although cases have been reported in Yemen and in small foci in Central and South America [6]. More than 120 million people in 37 countries in African, Latin America and Yemen are at risk of the disease and over 37 
million people have been infected mostly those living in poor rural communities [7]. Onchocerciasis is currently endemic in 36 countries, 30 of them are in Africa, South of the Sahara, in a wide zone that lies from Senegal to Ethiopia. The endemic area extends from South of the equator to Angola in the West and Tanzania in the east. Localized foci exist in Sudan and Yemen [6].

Through various control programmes led by the World Health Organization and based on vector control and/or mass administration of ivermectin [8], the global burden of the disease has been considerably reduced. More recently, attention has been focused on the Wolbachia organism, the endosymbiotic bacteria carried by adult worms and microfilariae [9]. With all these attempts to control the infectious disease, Ebonyi Central zone still suffer from its burden and the work-force in area has been greatly affected (Okonkwo and Ejiofor unpublished data).

This study is set to ascertain and compare the prevalence of the infection in Ebonyi North and Central Senatorial zones of Ebonyi State, Nigeria and to determine the age, occupational and sex distributions of the disease in the area. It is expected that this study will be an eyeopener to the government, non-governmental organisations as well as community-based organisations to mount various intervention programmes (like ivermectin provision, health education and water-way/water bodies decontaminations) and help reduce the burden of the infection in the area.

\section{Methods}

\subsection{The Study Setting and Population}

The study was carried out in Ebonyi Central and Ebonyi North Senatorial Zones of Ebonyi State with a population of 1,356,467 persons [10]. Ebonyi Central Senatorial Zone is made up of the following Local Government Areas (LGAs) viz: Ezza North, Ezza South, Ikwo and Ishielu while Ebonyi North Senatorial Zone includes Abakaliki, Ebonyi, Izzi and Ohaukwu L.G. As Ebonyi State is located in the Eastern part of Nigeria and is bounded to the North by Benue State, to the East by Cross River, to the South by Abia State and to the West by Enugu State. The state lies between longitude $7^{\circ} 35^{\prime} \mathrm{N}$ and latitude $6^{\circ} 45^{\prime} \mathrm{E}$. It experiences two seasons, rainy season (between April to October) and dry season (between November to March). The vegetation of the area is characterized by trees, shrubs, grasses and vegetative covers which are sparsely distributed. There are significant patches of swamp which form the basis of their agricultural activities. There are ponds, streams and other stagnant water bodies scattered all over the area. It has Ebonyi River which cuts across these zones. These rivers serves as the breeding sites of the vector Simulium damnosum whose consistent bites to the rural dwellers who use these rivers as their source of water for drinking, bathing, washing and other domestic activities, results to river blindness the most serious complications of Onchocerciasis. The study area is inhabited by different categories of people which include civil servants, farmers, students, traders, drivers, laborers but the majority is farmers who cultivate large quantities of rice, yam and cassava. All these activities predispose them to the bite of the black flies.

\subsection{Sample Collection}

A sample size of 500 persons, made up of males and females matched for ages, were recruited randomly from the two zones. One half came from one zone and the other half came from the other zone, ages were matched. This sample size was determined using Yamane (1973) [11] methods for calculating the sample size from a finite population.

$\mathrm{n}=\mathrm{N} /\left(1+\mathrm{Ne}^{2}\right)$

Where $\mathrm{n}=$ desired sample size, $\mathrm{e}=$ Maximum accepted margin of error (0.05),

$\mathrm{N}=$ Population $=1,356,467$ persons $[10]$,

1 = Theoretical constant,

$\mathrm{n}=1,356,467 /(1+1,356,467 * 0.05 * 0.05)=$ 399.8820813,

The minimum number of participants that will give a significantly significant result is approximately 400 but the study used 500 patients. The 500 participants gave oral consent and were interviewed in native language to obtain demographic information such as age, education and occupation. This study mainly involved physical examinations, diagnosis and assessment of ocular and skin Onchocerciasis for all the 500 participants.

\section{3.}

\subsubsection{Skin Snip Biopsies/Nodule Excision}

This was based on finding the microfilariae of Onchocerca volvolus in skin biopsies and adult worm in excised nodules as described by Cheesbrough (2005) [12]. Skin snips was aseptically taken from the body of each patient by lifting a small piece of the skin using a sterile needle and then cutting off with a sterile razor blade. The skin snips were then placed in a conical centrifuge tube containing about $1 \mathrm{ml}$ of the fresh physiological saline and incubated for 4 hours. After incubation, the content of the tube was centrifuged at 500 to 1,000 Relative Centrifugal Force (RCF) for 5 minutes. The skin snips and sediments were examined microscopically for microfilariae of Onchocerca volvolus using x10 magnification. When samples are positive, microfilariae are seen wriggling in the saline.

\subsubsection{Assessment of Skin Onchocerciasis}

The 500 patients were physically examined for obvious signs of Onchocerciasis such as hanging groin, elephantiasis, depigmentation (leopard skin), visible and palpable nodules, pruritis as well as dermal fibrosis and atrophy.

\subsubsection{Assessment of Ocular Onchocerciasis}

The visual acuity at far and near distance was tested using E chart and ability to count figures at distance up to $6 \mathrm{~m}$. The interior eye was examined for free floating intraocular microfilaria using ophthalmoscope.

\subsection{Materials}

2.4.1.

Razor blade (Nasset, Nigeria), needles, glass slide, cover slip, centrifuge (Hermie Labortechnic, Germany), incubator (Binder Labortechnic GMbH, Germany), 
microscope (Electromatic Ltd/Gillett and Sibert, Scotland), glass tube.

\subsubsection{Other Materials}

Snellen's visual acuity chart, pen light and Ophthalmoscope.

\subsection{Statistical Analysis}

The data obtained were analyzed by percentages, bar charts, Chi-Square test and One Way ANOVA with Tukey's Multiple Comparison pre-Test.

\subsection{Consent}

All authors declare that 'verbal informed consent was obtained from the patient for publication of this report and accompanying image.

\subsection{Ethical Approval}

The authors have obtained all necessary ethical approval from the ethics committee of Anambra State University Teaching Hospital, Amaku in Awka. This confirms either that this study is not against the public interest, or that the release of information is allowed by legislation. "All authors hereby declare that all experiments have been examined and approved by the appropriate ethics committee and have therefore been performed in accordance with the ethical standards laid down in the 1964 Declaration of Helsinki.”

\section{Results and Discussion}

The summary of the prevalence of Onchocerciasis in all the LGAs of the two Senatorial Zones is shown in Table 1 below.

Table 1. Onchocercal Lesion Manifestation in Different LGAs

\begin{tabular}{|c|c|c|c|c|c|c|c|c|c|c|}
\hline \multirow[b]{2}{*}{$\begin{array}{l}\text { Senatorial } \\
\text { Zone }\end{array}$} & \multirow[b]{2}{*}{$\begin{array}{c}\text { Local } \\
\text { Government } \\
\text { Areas }\end{array}$} & \multicolumn{7}{|c|}{ Lesions } & \multirow[b]{2}{*}{$\begin{array}{c}\text { Total } \\
\text { Number } \\
\text { Infected }\end{array}$} & \multirow[b]{2}{*}{$\begin{array}{c}\text { Total } \\
\text { Number } \\
\text { Examined }\end{array}$} \\
\hline & & Nodules & $\begin{array}{c}\text { Leopard } \\
\text { Skin }\end{array}$ & Dermatitis & $\begin{array}{c}\text { Hanging } \\
\text { groin }\end{array}$ & $\begin{array}{c}\text { Low } \\
\text { Vision } \\
\text { a }\end{array}$ & $\begin{array}{c}\text { Partial } \\
\text { Blindness } \\
\text { a }\end{array}$ & $\begin{array}{c}\text { Total } \\
\text { Blindness } \\
\mathrm{a}\end{array}$ & & \\
\hline \multirow{5}{*}{$\begin{array}{l}\text { bonyi } \\
\text { North }\end{array}$} & Ezza North & 0 & 1 & 1 & 0 & 12 & 4 & 2 & $\begin{array}{c}20 \\
(36.4 \%)\end{array}$ & 55 \\
\hline & Ezza South & 2 & 2 & 4 & 1 & 8 & 2 & 2 & $\begin{array}{c}21 \\
(29.5 \%)\end{array}$ & 71 \\
\hline & Ikwo & 1 & 2 & 3 & 0 & 11 & 6 & 1 & $\begin{array}{c}24 \\
(40.6 \%)\end{array}$ & 59 \\
\hline & Ishielu & 1 & 1 & 1 & 0 & 10 & 2 & 2 & $\begin{array}{c}17 \\
(26.1 \%)\end{array}$ & 65 \\
\hline & $\begin{array}{l}\text { Total number } \\
\text { infected (\%) }\end{array}$ & $4(1.6)$ & $6(2.1)$ & $9(3.6)$ & $1(0.4)$ & $4(16.4)$ & $14(5.6)$ & $7(2.8)$ & $\begin{array}{c}82 \\
(32.8 \%)\end{array}$ & 250 \\
\hline \multirow{5}{*}{$\begin{array}{l}\text { Ebonyi } \\
\text { Central }\end{array}$} & Abakaliki & 1 & 2 & 4 & 0 & 4 & 3 & 1 & $\begin{array}{c}14 \\
(28.0 \%)\end{array}$ & 50 \\
\hline & Ebonyi & 1 & 1 & 2 & 0 & 9 & 3 & 1 & $\begin{array}{c}17 \\
(32.2 \%)\end{array}$ & 53 \\
\hline & Izzi & 0 & 1 & 3 & 0 & 14 & 2 & 0 & $\begin{array}{c}23 \\
(29.8 \%)\end{array}$ & 77 \\
\hline & Ohaukwu & 0 & 1 & 6 & 0 & 11 & 2 & 1 & $\begin{array}{c}19 \\
(27.1 \%)\end{array}$ & 70 \\
\hline & $\begin{array}{l}\text { Total Number } \\
\text { infected (\%) }\end{array}$ & $2(0.8)$ & $5(2.0)$ & $15(6.0)$ & 0 & $\begin{array}{c}38 \\
(15.2)\end{array}$ & $10(4 \%)$ & 3 (1\%) & $\begin{array}{c}73 \\
(29.3 \%) \\
\end{array}$ & 250 \\
\hline
\end{tabular}

This study revealed a total prevalence rate of $31.0 \%$ in the two Senatorial Zones. Ebonyi Central Senatorial Zone had 32.8\% rate of infection while Ebonyi North Senatorial Zone had $29.2 \%$ prevalence. This study reveals a higher Onchocerciasis prevalence in the area compared to $26.9 \%$ previously reported [13] in Onchocerciasis endemic area of Enugu state but lower prevalence compared to 33.35\% reported [14] in Ebonyi State generally. The lower prevalence seen in this study may be due to little public awareness campaign/education on-going in Ebonyi North senatorial zone. This study and earlier ones shows the urgent attention needed to curtail the burden of the disease in the two states. A Chi-Square test shows that there is no significant difference in prevalence of the infection in the two zones (Ebonyi North and Central) at $\alpha<0.5$ significant level $(\mathrm{P}$ value $=0.7787)$.

One-way analysis of variance of the number of cases of the disease (prevalence) in the different Local Government Areas (L.G.As) shows that there is no significant difference in the prevalence rate of the disease in the L.G.As $(P=0.9986)$. Reports $[15,16]$ show that the occurrence of Onchocerciasis varies from one geographical region to another and these zones belong to a common region. The prevalence of Onchocerciasis in Nigeria has significant variation in different villages with the villages that are near the breeding sites of vector showing higher infection prevalence [17].

Ebonyi Central Zone had a higher Onchocerciasis prevalence rate of $32.8 \%$ (although not statistically significant) than Ebonyi North Senatorial Zone with 29.2\% occurrence. This is so because Ebonyi Central Zone is known for their farming activities, being naturally endowed with swamp and the Ebonyi River. Another occupational predisposing factor to the higher prevalence of the disease in Ebonyi Central is the digging of sand from the river for commercial purposes. These unskilled workers dig and carry sand from the river banks to sell to buyers who use the sand for building purposes. These activities (carried out by men only) expose them more to the bite of the infected black fly. (See Table 3 and Figure 1 below).

The study (Table 4) also show that farmers had significantly $(p<0.05)$ higher prevalence rate than trades, civil servants, drivers or students with higher prevalence rate of 22.8\% for Ebonyi Central Zone than Ebonyi North Zone $(21.6 \%)$. Field workers are more predisposed to the bite of the infected black fly [14,17].

Tukey's Multiple Comparison Test of Occupational Distribution of Onchocercal Lesion (Figure 1) below shows that there is significant difference in the prevalence 
of the disease between "Traders versus Farmers", "Traders versus Students", "Farmers versus Students" and "Farmers versus Civil Servants" but not between Traders versus Civil Servants and Students versus Civil Servants at $\alpha<$ 0.05. It is understandable that Traders are next to Farmers in high prevalence as many of these traders engage in sand digging trade.

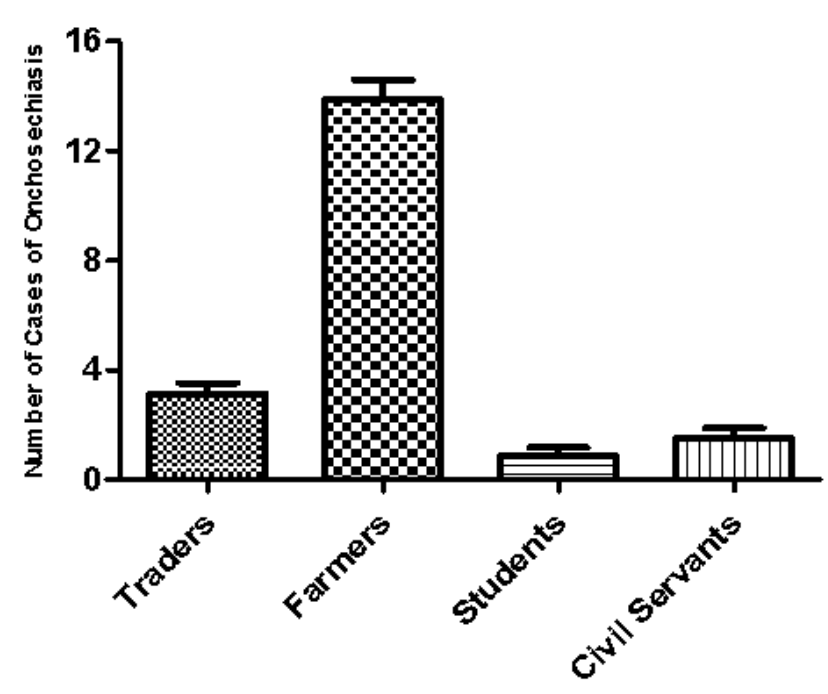

Figure 1. Occupational Distribution of Onchocercal Lesion

The prevalence of Onchocerciasis was significantly higher $(\mathrm{p}<0.05)$ among males $(35.41 \%)$ than females (24.10\%) subjects in the two Zones combined (Table 2). In Ebonyi Central Zone, $38.71 \%$ males and $23.16 \%$ females were infected while in Ebonyi North Zone, it was $32 \%$ and $25 \%$ respectively. The differences in infection rate with regards to sex may be due to endemicity [17], occupational exposure and susceptibility of individual $[14,18]$. Males work longer in the farm, and with bare body, than the females thereby making them more prone to the bite of the black flies. Also, they are the ones involved in sand digging. The findings in this study differ from another report [15] in Ovia North East L.G.A of Edo State Nigeria where females had 93\% Onchocerciasis infection and males $74.5 \%$. Rampant practice of Onchocercal nodules excision by natives have been observed in Nigeria [19].

The 40-49 years age group had the highest rate of Onchocerciasis with $(21.6 \%$ in the Central Zone and $16.0 \%$ in the North Zones (Table 3). This could be because this age group is mostly farmers. The manifestation of Onchocercal lesions follows the same pattern in their distribution in the two zones. A similar observation to the findings of this study has been reported [20,21].

Onchocercal lesions such as Nodules, leopard skin, hanging groin and blindness were observed in subjects examined. Pruritis/dermatitis (Figure 2) 24 (4.8\%) was found in all age groups but is higher in the older age groups of 30-59 year. Leopard skin was found in 11 (2.2\%) patients, Nodules in $6(1.2 \%)$ persons, and Hanging groin in $1(0.2 \%)$ patient examined. Onchocerciasis lesions manifestation was more in males than females especially in Ebonyi Central Zone with subjects from 30-59 years showing higher Onchocerca volvulus infection (Table 1). The prevalence of physical symptoms was low and a similar observation has been reported [22].

Our findings revealed that visual acuity impairment and blindness was significantly different $(\mathrm{P}<0.05)$ in the two Senatorial Zones. Low vision had the highest occurrence (12.0\%) in both Zones followed by partial blindness (4.6\%). Ebonyi North Senatorial Zone had higher prevalent rate than Ebonyi Central Senatorial Zone. Blindness which was the most serious complication of Onchocerciasis had low prevalence rate $(2.4 \%)$ in both Zones. Ebonyi Central Senatorial Zone had 7 (2.8\%) persons who were affected while Ebonyi North Senatorial Zone had 3 (1.2\%) persons affected (Figure 3 and Table 1).

The low occurrence of blindness in this study was in contrast to the high blindness rate previously reported $[23,24]$ in the Savanna areas. This difference in prevalence rate of blindness according to a report [25] was attributed to the more invasiveness and pathogenic nature of microfilariae strain of Savannah for the cornea than those of the rainforest strain. Lack of vitamin A encourages the free spread of microfilariae through the tissues especially the eyes leading to blindness [26], hence the low blindness rate in this study may be attributed to increased consumption of vitamin A through palm oil by the people living in Ebonyi Central and Ebonyi North Senatorial Zone. Males recoded high blindness prevalence rate than female subjects in both Zones. The lower incidence of Onchocercal blindness and other lesions in the females was attributed to possible unexplainable hormonal effects [27].

Table 2. Sex Distribution of Onchocercal Lesions in the two Senatorial Zones

\begin{tabular}{|c|c|c|c|c|c|c|c|c|c|c|c|}
\hline \multirow{2}{*}{$\begin{array}{c}\text { Senatorial } \\
\text { Zone }\end{array}$} & \multirow{2}{*}{ Gender } & \multicolumn{7}{|c|}{ Lesions } & \multirow{2}{*}{$\begin{array}{l}\text { Total } \\
\text { Number } \\
\text { Infected }\end{array}$} & \multirow{2}{*}{$\begin{array}{c}\text { Total } \\
\text { Number } \\
\text { Examined }\end{array}$} & \multirow{2}{*}{$\begin{array}{l}\text { Percent } \\
\text { Infectec }\end{array}$} \\
\hline & & Nodules & $\begin{array}{l}\text { Leopard } \\
\text { Skin }\end{array}$ & Dermatitis & $\begin{array}{l}\text { Hanging } \\
\text { groin }\end{array}$ & $\begin{array}{l}\text { Low } \\
\text { Vision } \\
\text { a }\end{array}$ & $\begin{array}{c}\text { Partial } \\
\text { Blindness } \\
\text { a }\end{array}$ & $\begin{array}{c}\text { Total } \\
\text { Blindness } \\
\text { a }\end{array}$ & & & \\
\hline \multirow{2}{*}{$\begin{array}{l}\text { Ebonyi } \\
\text { Central }\end{array}$} & Male & 3 & 4 & 6 & 1 & 31 & 10 & 5 & 60 & 155 & 38.71 \\
\hline & Female & 1 & 2 & 3 & 0 & 10 & 4 & 2 & 22 & 95 & 23.16 \\
\hline \multirow{2}{*}{$\begin{array}{l}\text { Ebonyi } \\
\text { North }\end{array}$} & Male & 2 & 2 & 10 & 0 & 26 & 6 & 2 & 48 & 150 & 32.00 \\
\hline & Female & 0 & 3 & 5 & 0 & 12 & 4 & 1 & 25 & 100 & 25.00 \\
\hline
\end{tabular}


Table 3. Onchocerciasis Manifestation by Age

\begin{tabular}{|c|c|c|c|c|c|c|c|c|c|c|}
\hline \multirow{3}{*}{$\begin{array}{l}\text { Senatorial } \\
\text { Zone }\end{array}$} & \multirow{3}{*}{$\begin{array}{c}\text { Age } \\
\text { Group } \\
\text { (Years) }\end{array}$} & \multirow{2}{*}{\multicolumn{7}{|c|}{ Lesions }} & \multirow{3}{*}{$\begin{array}{c}\text { Total } \\
\text { Number } \\
\text { Infected }\end{array}$} & \multirow{3}{*}{$\begin{array}{c}\text { Total } \\
\text { Number } \\
\text { Examined }\end{array}$} \\
\hline & & & & & & & & & & \\
\hline & & Nodules & $\begin{array}{l}\text { Leopard } \\
\text { Skin }\end{array}$ & Dermatitis & $\begin{array}{l}\text { Hanging } \\
\text { groin }\end{array}$ & $\begin{array}{c}\text { Low } \\
\text { Vision }^{\text {a }}\end{array}$ & $\begin{array}{c}\text { Partial } \\
\text { Blindness }\end{array}$ & $\begin{array}{c}\text { Total } \\
\text { Blindness }\end{array}$ & & \\
\hline & $20-29$ & 0 & 0 & 4 & 0 & 5 & 2 & 11 & $22(8.8)$ & 43 \\
\hline & $30-39$ & 1 & 0 & 2 & 0 & 11 & 3 & 17 & 34 (13.6) & 58 \\
\hline Ebonyi & $40-49$ & 1 & 4 & 1 & 0 & 15 & 5 & 28 & 54 (21.6) & 84 \\
\hline \multirow[t]{4}{*}{ Central } & $50-69$ & 2 & 2 & 2 & 1 & 10 & 4 & 26 & 47 (18.8) & 65 \\
\hline & $\begin{array}{c}\text { Total (\%) } \\
\text { infected }\end{array}$ & $4(1.6)$ & $6(2.4)$ & 9 (3.6) & $1(0.4)$ & $\begin{array}{c}39 \\
(15.6)\end{array}$ & $14(5.6)$ & 82 (32.8) & 155 (62.0) & 250 \\
\hline & $20-29$ & 0 & 0 & 3 & 0 & 14 & 1 & 18 & 36 (14.4) & 78 \\
\hline & $30-39$ & 0 & 1 & 4 & 0 & 9 & 3 & 17 & 34 (13.6) & 85 \\
\hline \multirow{3}{*}{$\begin{array}{l}\text { Ebonyi } \\
\text { North }\end{array}$} & $40-49$ & 1 & 3 & 2 & 0 & 11 & 2 & 21 & $40(16.0)$ & 64 \\
\hline & $50-69$ & 1 & 1 & 6 & 0 & 4 & 4 & 17 & 33 (13.2) & 44 \\
\hline & $\begin{array}{l}\text { Total (\%) } \\
\text { infected }\end{array}$ & $2(0.8)$ & $5(2.0)$ & $15(6.0)$ & $0(0.0)$ & $\begin{array}{c}38 \\
(15.2)\end{array}$ & $10(4.0)$ & 73 (29.2) & 143 (57.2) & 250 \\
\hline
\end{tabular}

Table 4. Occupational Distribution of Onchocercal Lesion

\begin{tabular}{|c|c|c|c|c|c|c|c|}
\hline \multirow{2}{*}{ Senatorial Zone } & \multirow{2}{*}{ Local Government Areas } & \multicolumn{4}{|c|}{ Occupation } & \multirow{2}{*}{ Total Number Infected } & \multirow{2}{*}{ Total Number Examined } \\
\hline & & Traders & Farmers & Students & Civil Servants & & \\
\hline \multirow{5}{*}{ Ebonyi North } & Ezza North & 5 & 13 & 1 & 1 & $20(36.36)$ & 55 \\
\hline & Ezza South & 3 & 15 & 0 & 3 & $21(29.57)$ & 71 \\
\hline & Ikwo & 4 & 16 & 2 & 2 & $24(42.85)$ & 56 \\
\hline & Ishielu & 2 & 13 & 1 & 1 & $17(26.15)$ & 65 \\
\hline & Total (\%) infected & $14(5.6)$ & $57(22.8$ & $4(1.6)$ & $7(2.8)$ & $82(32.8)$ & 250 \\
\hline \multirow{5}{*}{ Ebonyi Central } & Abakaliki & 3 & 11 & 0 & 0 & $14(28.00)$ & 50 \\
\hline & Ebonyi & 2 & 12 & 0 & 3 & 17 (32.08) & 53 \\
\hline & Izzi & 4 & 17 & 1 & 1 & $23(29.87)$ & 77 \\
\hline & Ohaukwu & 2 & 14 & 2 & 1 & $19(27.14)$ & 70 \\
\hline & Total (\%) infected & $11(4.4)$ & $54(21.6)$ & $3(1.2)$ & $5(2.0)$ & $73(29.2)$ & 250 \\
\hline
\end{tabular}

As shown in FIGURE 2 below, of the 250 patients examined for visual acuity in Ebonyi Central Senatorial Zone, 7 (2.8\%) patients were blind (2/60) while 14 (5.6\%) patients had visual acuity of between 5/60-3/60 which indicates partial blindness, 41 (16.4\%) patients had visual acuity of between 6/24 - 6/60 which is low vision. In Ebonyi North Senatorial Zone, out of 250 patients examined, $3(1.2 \%)$ patients are blind (2/60) while 9 (3.8\%) patients had partial blindness (5/60 - 3/60) and 38 (15.2\%) patients had low vision (5/24 -6/60).

A $t$ - test analysis of the result, at $\alpha<0.05$ level of significance, shows that there is no statistical difference in the visual acuity levels of the participants from the two zones in Ebonyi State $(\mathrm{P}$ value $=0.2999)$.

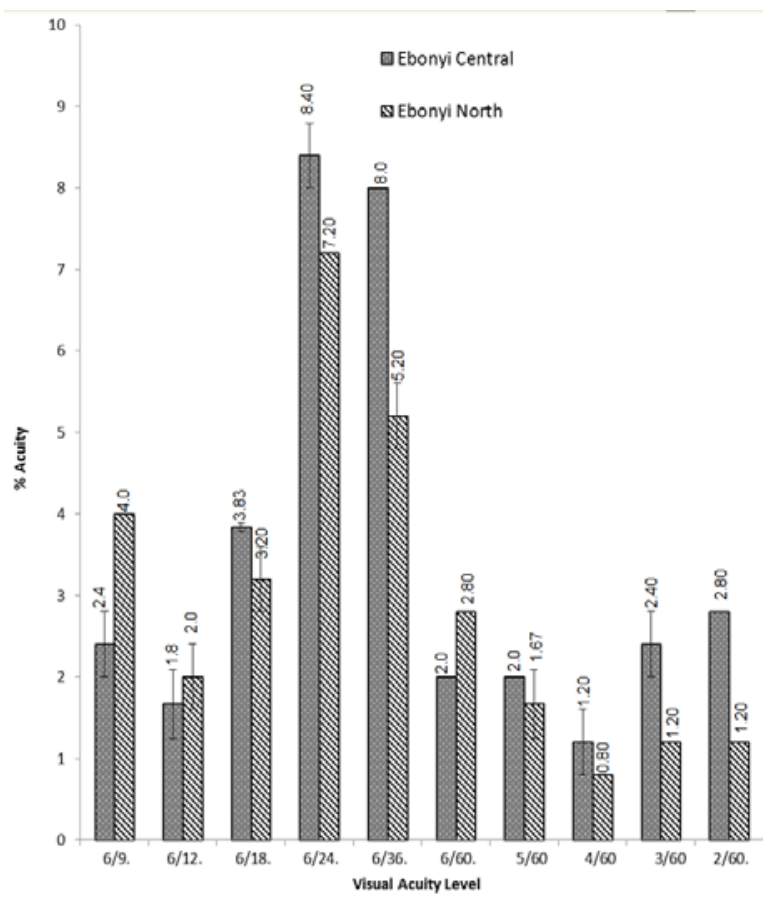

Figure 2. Distribution of Visual Acuity among Onchocerciasis Infected Persons between 20 -59 Years in Ebonyi Central and North Zones
Figure 3 below shows the picture of a patient with leopard skin observed during the study. The leg is scaly and very itchy.

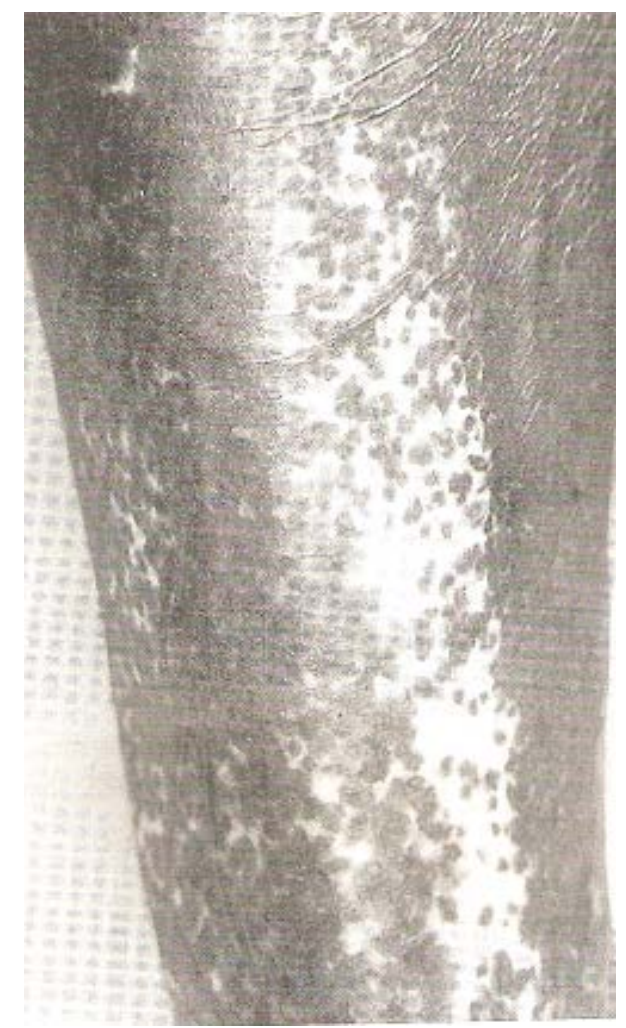

Figure 3. Picture of patient with leopard skin (shin depigmentation) observed during the study

\section{Conclusion}

The findings obtained from this work suggested that Ebonyi Central and North Senatorial Zones are Onchocerciasis hypo-endemic Zones having the prevalence rate of $32.8 \%$ and $29.2 \%$ respectively. Sex, age 
and occupation are related to Onchocerciasis infections in both Zones. Males are more infected than females.

In view of these findings, it is recommended that:

1. Government at all levels should give Onchocerciasis programme high priority and particularly so in Ebonyi Central Zone.

2. That Ivermectin drug should constantly be made available and accessible to the people.

3. That awareness campaign should be carried out in the area through electronic media and health educators.

4. Efforts should be made to eradicate the vector fly by spraying chemicals along the water-ways and up on the water bodies using helicopters.

\section{List Of Abbreviations}

1. Local Government Areas (LGAs).

2. Relative Centrifugal Force (RCF).

3. African Programme for Onchocerciasis Control (APOC).

\section{Competing Interests}

The authors declare that they have no competing interests.

\section{Authors' Contributions}

Nworie Okoro conceptualized the study, Ukpabi Nkechinyere Nwali implemented the study and interpreted the data, Oli Angus Nnamdi wrote the first draft and did part of the statistical analysis, Okonkwo Chuma Innocent was the Medical doctor that examined the patients and diagnosed the disease, Okoli Chukwudum Somadina designed the study while Ejiofor Obiora Shedrack critically read the draft for intellectual content.

\section{Endnote}

${ }^{\mathrm{a} C l a s s i f i c a t i o n ~ o f ~ b l i n d n e s s ~}$

Good vision $=6 / 9-6 / 18$, Low vision $=6 / 24-6 / 60$, Partial blindness $=5 / 60-3 / 60$, Blindness $=2 / 60$ [28].

\section{References}

[1] Gerald, D.S and Lany, S.R. (2010) Foundations of Parasitology: McGraw-Hill, New York. Eight Editions. pp. 468-472.

[2] Tekle, A.H., Elhassan, E., Isiyaku, S., Amazigo, U.V; Bush, S., Noma, M., Cousesns, S., Abiose, A. and Remme, J.H. Impact of long-term treatment of Onchocerciasis with Ivermectin in Kaduna State, Nigeria: First evidence of the potential for elimination in the operational area of the African programme for Onchocerciasis Control. Parasite and Vector; 2012, 5: 28-31.

[3] Thylefors, Björn I, Négrel, A. D, Pararajasegaram Ramachandra and Dadzie, K. Y Global data on blindness. Bulletin of the World Health Organization; 1995, 73 (1): 115-121.

[4] Pion, S.D., Kamgno, J., Demanga-Ngangue and Boussinesq, M.E. Excess Mortality associated with blindness in the Onchocerciasis focus of Mbam valley, Cameroon. Ann. Trop. Med. Parasitol; 2002, 96 (2): 181-189.

[5] Nwoke, B.E.B. Ivermectin, the incredible Drug against Human Onchocerciasis. Medicare Journal; 1992, 5: 1-2.
[6] World Health Organization. Status of Onchocerciasis in African Programme for Onchocerciasis Control (APOC) Countries, TDR /AFR/RP/951.6, Geneva, 2008.

[7] World Health Organization. Onchocerciasis and its control. Report of a WHO Expert committee on Onchocerciasis control. WHO Technical Report series; 1995, 852: 1-104. Geneva.

[8] Tielsch, J.M and Beech, A. Impact of ivermectin on illness and disability associated with Onchocerciasis. Trop. Med. Int. Health; 2004, 9 (4): 45-56

[9] Hoerauf, A.,Buttner, D.W., Adjei, $\mathrm{O}$ and Pearlman, E. Onchocerciasis, B M J., 2003, 326 (7382). 207-210.

[10] National Population Commission: Population Distribution by Sex, State, LGA \& Senatorial district; Federal Republic of Nigeria, 2006 Population and Housing Census: PRIORITY TABLE, Volume III (April, 2010).

[11] Yamane, T. Statistics: An Introductory Analysis, 2nd ed., New York: Haper and Row Press, USA. 1973, p. 45.

[12] Cheesbrough, M. District Laboratory Practice in Tropical Countries Part 1. Cambridge University Press, New York. Second Edition. 2005, pp. 291-295.

[13] Nwaorgu, O. C., Ohaegbulam, A., Onweluzor, I. E., Alor, E. T., Nweke, L., Agu, M. I., and Emeh, E. Results of a large scale Onchocerciasis survey in Enugu State, Nigeria. Journal of Helminthology, 1994, 68, 155-159.

[14] Iroha, I. R., Okonkwo, C. I., Ayogu, J. E., Orji, A. E and Onwa, N. C. Epidemiology of Human Onchocerciasis among farmers in Ebonyi State, Nigeria. International Journal of Medicine and Medical Science; 2010, 2 (8): 246-250.

[15] Akinboye, D.O., Okwong, E., Ajiteru, N; Fawole, O., Agbolade, O.M., Ayinde, O.O., Amosu, A.M., Atuloma, N.O.S., Odula, O., Owodunni, B.M., Rebecca S.N and Falade, M. Onchocerciasis among inhabitants of Ibarapa Local Government community of Oyo State, Nigeria. Biomed. Res., 2010, 21 (2): 174-178.

[16] Akinbo, F.O and Okaka C.E. Prevalence and Socio-Economic Effects of Onchocerciasis in Ovia North East Local Government Area of Edo State, Nigeria. Rivista Parasitologic. 2005, 22 (3): 215-221.

[17] Onwuliri, C.O.E., Nwoke, B.E.B., Lawal, I.A and Iwuala, M.O.E. Onchocerciasis in Plateau State of Nigeria. II. The prevalence among residents around the Assob River Area. Ann. Trop. Med. Parasitol; 1987, 81: 49-52.

[18] Nwoke, B.E.B., Shiwaku, K and Takahashi, H. Nigerian Onchocerciasis: Epidemiological perceptive: J. Trop. Med. Hyg., 1991, 19 (2): 191-201.

[19] Abanobi O. C., Edungbola L. D., Obiri G. and Nwoke B. E. B., Onchocercal Nodules: Prevalence and the Practice of Lay Nodulectomy in Mballa, Isuochi, Abia State, Nigeria. J. Nig. Opt. Assoc. 1999, 6 51-53.

[20] Nwoke, B.E.B. The Socio-economic aspects of human Onchocerciasis in Africa: Present appraisal. J.. Hyg. Epidemiol. Microbiol Immunol; 1995, 33: 19- 28.

[21] Somorin, A.O. “Onchocerciasis”. Int. J. Dermatol; 1983, 22: 182281.

[22] Anosike, J. C., Onwuliri, C. O. E. and Onwuliri, V. A. The prevalence, intensity and clinical manifestation of Onchocerca volvulus infection in two Local Government Area of Bauchi State, Nigeria; Int. J. Hyg. Envron and Health; 2001, 203 (5-6): 459-464.

[23] Dipolu, O.O. Onchocerciasis in Benue State of Nigeria. The prevalence of the disease among the population in Manor. Int. J. Zoonosis; 1984, 10: 85-752.

[24] Budden, F.H. Comparative Study of Ocular Onchocerciasis in Sudan -Savanna and Rainforest, Trans. Roy. Trop. Med. Hyg., 2000, 57: 64-70.

[25] Duke, B.O.L. Strains of Onchocerca volvulus and their pathogenicity, Trop. Med. Parasitol; 1976, 22: 21-22.

[26] Rodgers, F.C. A review of recent advances in the scientific knowledge of the symptomatology, pathology and pathogenesis of Onchocercal infections, Bulletin of World Health Organization, 1998, 27: 429-448.

[27] Anderson, J and Fuglsang, H. Variation in numbers of microfilaria of Onchocerca volvolus in the anterior chamber of the human eye. Trans . Roy. Soc. Trop. Med Hyg., 1974, 67: 544-548.

[28] World Health Organization. The prevention of blindness, World Health Organization Technical Report 2003, No. 518. 